\title{
Risk of Cardiovascular Disease Associated with the Exposure of Particulate Matter ( $\left.\mathrm{PM}_{2.5}\right)$ : Review
}

\author{
Rabina Sinkemani1 ${ }^{1}$ Arjun Sinkemani², Xiaobo Li' ${ }^{1}$, Rui Chen ${ }^{1 *}$ \\ ${ }^{1}$ Southeast University School of Public Health, Nanjing, China \\ ${ }^{2}$ Southeast University School of Medicine, Nanjing, China \\ Email: ${ }^{*} 101011816 @ s e u . e d u . c n$
}

How to cite this paper: Sinkemani, R., Sinkemani, A., Li, X.B. and Chen, R. (2018) Risk of Cardiovascular Disease Associated with the Exposure of Particulate Matter $\left(\mathrm{PM}_{2.5}\right)$ : Review. Journal of Environmental Protection, 9, 607-618.

https://doi.org/10.4236/jep.2018.96038

Received: April 18, 2018

Accepted: May 28, 2018

Published: May 31, 2018

Copyright $\odot 2018$ by authors and Scientific Research Publishing Inc. This work is licensed under the Creative Commons Attribution International License (CC BY 4.0).

http://creativecommons.org/licenses/by/4.0/

\begin{abstract}
Association of particulate matter $\left(\mathrm{PM}_{2.5}\right)$ increases the risk of cardiovascular disease. Experimental and clinical evidences suggested that $\mathrm{PM}_{2.5}$ is directly linked with cardiovascular disease. $\mathrm{PM}_{2.5}$ also plays an important role in the biological mechanisms influencing in the cardiovascular system. Here in this review, we tried to discuss that $\mathrm{PM}_{2.5}$ is associated with the increase risk of cardiovascular disease in which $\mathrm{PM}_{2.5}$ air pollutants enter through the alveolar of the lungs through the systemic circulation inducing cardiovascular disease. More studies need to be done for further understanding to clarify the interactions of $\mathrm{PM}_{2.5}$ components associated with cardiovascular disease.
\end{abstract}

\section{Keywords}

Particulate Matter, Air Pollution, Cardiovascular Disease, Risk

\section{Introduction}

Previous studies have evidenced particulate air pollution with adverse health effects relating with cardiovascular disease, and the ambient air pollution effect is linked with different diseases of cardiovascular with the upregulated cardiovascular mortality and morbidity [1] [2] [3]. The particulate matter (PM) with aerodynamic diameter $\leq 2.5 \mu \mathrm{m}$ can penetrate deep into the alveolar regions of the lung, which results in cardiovascular and other health effects. Many studies have been done for the better understanding the PM characteristics to observe the associated cardiovascular diseases [4] [5] [6]. The toxicological and epidemiological studies evidenced that $\mathrm{PM}_{2.5}$ component plays an important role in cardiovascular responses [2] [6]. Many studies done before have evidenced that the 
sources of air pollution which are responsible for the cardiovascular and other health effects are directly linked with the traffic-related particles [7]. It has been evidenced that the air pollutants PM, which enters the circulatory system easily induces systemic inflammation and hypercoagulability [8] [9], alters cardiac autonomic nervous system [10], induces in significant increased blood pressure [11] [12], and promotes cardiovascular diseases through oxidative pathway [13] [14]. Epidemiological studies reported that the air pollution exposure evidenced in the growth of cardiovascular health effects [15] [16] [17].

Cardiovascular disease in respect with cerebral vascular disease, coronary artery disease and peripheral artery disease are the leading cause of death worldwide [18]. Cardiovascular disease is associated with risk factors including family history, ageing, smoking, diabetes, hyperlipidemia and hypertension [19]. Importantly, the healthy life style may decrease the risk of cardiovascular disease in which one study suggested that Mediterranean diet helps in deceasing risk of cardiovascular disease, while the incidence of cardiovascular disease can be raised taking excessive amount of carbohydrate and high fat diets [20]. Thus, it became a global and socio-economic burden with significant increased populations is exposed to particulate matters [21]. PM components play an important role in the biological mechanisms associated with air pollution but the adverse effects in the cardiovascular outcomes are not fully understood till now. There were only limited number of studies done in this; where more studies are need to be done to better understand the features associated to $\mathrm{PM}_{2.5}$ and cardiovascular disease in a large population so that it could help in deteriorating the risk of cardiovascular disease.

\section{Biomarkers Associated with Exposures to $\mathrm{PM}_{2.5}$ and CVD}

Experimental data have demonstrated that $\mathrm{PM}_{2.5}$ may mediate a systemic cellular inflammatory response through TLR4/NADPH oxidase-dependent mechanisms [22]. The human studies done previously suggested that increase in circulating biomarkers of inflammation, coagulation, and vasoconstriction following PM exposure can be one of the main pathways [2]. In the study by Chen $\mathrm{R}$ et al., they found positive associations of $\mathrm{PM}_{2.5}$ CVD biomarkers, which include six inflammatory markers fibrinogen, CRP, ICAM-1, VCAM-1, P-selectin, MCP-1; three coagulation markers PAI-1, CD40-L, vWF; and the vasoconstrictor ET-1 [23]. This study evidenced vital insights in the characteristics of $\mathrm{PM}_{2.5}$ that could implicate the CVD prevention.

One another study suggested that circulating inflammatory biomarkers may be increased by short term inhalation of particulate matters [2]. These biomarkers included CRP, fibrinogen, ICAM-1, VCAM-1. P-selectin and MCP-1. Another panel study done by Wu S et al. suggested that the PM2.5 constituents associated with the biomarkers of inflammation, coagulation and homocysteine in the context of traffic related air pollution play the vital role influencing the CVD [24]. They also evidenced that the circulatory biomarkers of TNF- $\alpha$, fibri- 
nogen, PAI-1 and P-selectin more likely responsive to $\mathrm{PM}_{2.5}$ metal contents and $\mathrm{Zn}, \mathrm{Co}, \mathrm{Mn}$ and $\mathrm{NO}_{3}$ were more likely associated with these markers.

These biomarkers are directly related with CVD which are associated with short term air pollution exposure and these biomarkers are predicted to be the risk of CVD [25] [26] [27]. A panel study in patients with chronic pulmonary disease found the increased concentration of air pollution are directly associated with the biomarkers of inflammation and coagulation [28]. Growing evidence suggested that ambient air pollution is associated with exacerbation of the chronic diseases. These biomarkers of systemic inflammation and traffic related air pollutants are directly associated with the risk of CVD morbidity and mortality leading to platelet activation and decreased antioxidant enzyme activity in elderly people [16] [17].

\section{Exposure to $\mathrm{PM}_{2.5}$ Components or Constituents}

The associations of exposures to PM components were mostly found as organic carbon (OC) and transition metals (iron, manganese, zinc, etc.) [29] [30]. Airborne PM is a constituent of different types of chemical which induce in the biological effects of total PM [2] [31]. In addition, PM related to different sources (e.g., traffic, secondary) also has been associated with cardiovascular effects in recent studies [15] [17] [32]. The effects of different PM chemical properties in the above mentioned biological mechanisms connecting air pollution to adverse the cardiovascular diseases are not well understood till now. $\mathrm{PM}_{2.5}$ contains different types of chemical components, and some studies have reported whether these chemical components may have differential adverse effects on cardiovascular system [33] [34] but it still remains unclear if these components are responsible in the cardiovascular diseases effected by $\mathrm{PM}_{2.5}$.

Heavy haze-fog episodes have frequently occurred in recent years [35] [36]. For example, starting in early January 2013, Beijing experienced multiple prolonged periods of severe smog; the peak hourly concentration of ambient $\mathrm{PM}_{2.5}$ soared to $800 \mu \mathrm{g} / \mathrm{m}^{3}$, and the annual ambient $\mathrm{PM}_{2.5}$ concentration in 2013 reached $89.5 \mu \mathrm{g} / \mathrm{m}^{3}$ [37]. The extremely high ambient $\mathrm{PM}_{2.5}$ concentrations have attracted extensive public attention because of the adverse health effects. However, evidences by the previous studies suggested that the effects of different particle constituents in the air pollution-related cardiovascular effects is generally lacking which might be limited number studies done in the particle constituents [35].

Among the $\mathrm{PM}_{2.5}$ components, metals $\mathrm{Fe}, \mathrm{Zn}, \mathrm{Cd}, \mathrm{Mn}$ and $\mathrm{Pb}$ come from the traditional source of industrial wastages, and metals $\mathrm{Al}, \mathrm{Mg}, \mathrm{Ba}$ and $\mathrm{Ti}$ (and part of $\mathrm{Fe}$ and $\mathrm{Mn}$ ) originating from mineral aerosols that would be likely from re-suspended road dust and long-range transported dust; $\mathrm{SO}_{4}^{2-}, \mathrm{NO}_{3}^{-}$and Se are mainly generated from coal burning whereas the chemical transformation that formed the secondary aerosols can also produce a lot of $\mathrm{SO}_{4}^{2-}$ and $\mathrm{NO}_{3}^{-}$ [38]; $\mathrm{Cl}^{-}$and $\mathrm{F}^{-}$generally indicate the waste incineration and part of coal burn- 
ing in the rural areas; additionally, some metals $\mathrm{Fe}, \mathrm{Zn}, \mathrm{V}, \mathrm{Mn}$ and $\mathrm{Pb}$ may also be contained in traffic-related emissions in addition to the carbonaceous fractions and gases [39].

\section{The Health Effects of Indoor Air Pollution}

Indoor air pollution from the past can be described when humans first moved to temperate climates during winter season. People used to fire inside the house for different purpose like cooking and warmth light. As a result, 2 million people deaths were estimated mostly in developing countries [40]. House hold biomass fuel combustion led to chronic bronchitis with the high exposure of cooking stoves worldwide being used by the people [41]. They cook inside the house typically or poorly functioned stoves which leads the air pollution and increase the risk of respiratory disease and other health problems. It may expose to infant, women, men, and elderly. Person who spends more time in kitchen, they may have higher risk of getting the chance of cardiovascular and respiratory diseases. Open wooden fires or poorly functioned stoves were typically used which leads to the increased air pollution [42].

Cultural practice common in developing countries may promote exposure of infants, women, the elderly and the sick. Since it is the woman who generally cooks, their exposure is much higher than men [43]. Most mothers carry their children on their back while she cooks. During those time, their infants spent most of the times breathing smokes. Some of the most vulnerable people typically spend more than $95 \%$ of their time indoor. The gender difference was not easy to explain because men may have an increased risk of cardiovascular events [44], but increased depositions of particles in the lung and higher airway responsiveness could make women more vulnerable to $\mathrm{PM}_{2.5}$ pollution [45]. Air quality and human health are strongly linked.

The health related compounds emitted from solid fuel cook stoves include: carbon monoxide ( $\mathrm{CO}$ ), sulfur dioxide ( $\mathrm{SO}_{2}$, coal burning stove), $\mathrm{PM}$ and some hydrocarbon constituents. Solid fuels which are used as household, led to high exposures to unhealthy indoor air pollution, particularly for those women working and cooking indoors [43]. Significant long-term exposure in environments containing the products of incomplete combustion and particulates found in solid-fuels moke can cause chronic diseases as well as other adverse health effects. A recent study conducted in Yunnan province of China evidenced strong correlation between residential coal use and lung cancer occurrence [46] [47].

\section{Hospital Emergency Visits with the Exposure to $\mathbf{P M}_{2.5}$}

$\mathrm{PM}_{2.5}$ leads to more than 1.2 million deaths ranking at number 4 among all those risk factors conducing the health burden in China [21]. The main reasons that were associated with emergency hospital visit are related with the burning of fossil fuel (e.g., coal and oil). These lead in cardiovascular and respiratory diseases which are the major causes of emergency hospital visits. Previously, the 
studied evidenced that the exposures to $\mathrm{PM}_{2.5}$ leading cardiovascular diseases lead to hospital emergency visits and hospital admissions, have been extensively reported in the U.S. and Europe [48] [49] [50]. $\mathrm{PM}_{2.5}$ exposure and cardiovascular morbidity is more crucial in China than in other developed countries [51]. Moreover, only a few studies have been performed in other large Asian countries [52] [53] [54].

It is clear that epidemiological evidence reported in Western countries cannot be directly generalized to Asian populations [53]. Therefore, the cardiovascular effects of $\mathrm{PM}_{2.5}$ exposure require further study in Asia. With rapid urbanization and industrialization during the past three decades, $\mathrm{PM}_{2.5}$ air pollution in China has become a serious public health problem [35] [37]. There are a few studies that have examined the associations between $\mathrm{PM}_{2.5}$ and cardiovascular morbidity in Beijing [1] [55] [56]. However, these studies only used emergency hospital visits data from one hospital and $\mathrm{PM}_{2.5}$ data from a fixed monitoring station, which might make the results insufficiently representative due to Beijing's large population size and wide residential distribution. Another study conducted in Beijing only evaluated the effects of $\mathrm{PM}_{2.5}$ on ischemic heart disease and did not include other cardiovascular diseases, such as cerebrovascular disease [57].

Moreover, the $\mathrm{PM}_{2.5}$ monitoring data have been released by the Beijing Environmental Protection Bureau (BEPB) since October 2012 and can be accessed by the general population [58]. The availability of data from this monitoring network provided us with an opportunity to assess the short-term effects of $\mathrm{PM}_{2.5}$ on cardiovascular morbidity. However, few reports have directly evaluated the effects of $\mathrm{PM}_{2.5}$ on total and cause-specific respiratory diseases using hospital emergency visits as a morbidity indicator. In addition, most of these studies were conducted in Western developed countries; however, because of the different level of effects, such as ambient $\mathrm{PM}_{2.5}$ levels, characteristics of ambient $\mathrm{PM}_{2.5}$, population susceptibility, and weather patterns, there is still a need to assess the health effects of $\mathrm{PM}_{2.5}$ exposures in developing countries.

\section{Conclusion}

Our review evidenced that particulate matter $\left(\mathrm{PM}_{2.5}\right)$ is directly associated with the risk factors of cardiovascular disorders. $\mathrm{PM}_{2.5}$ air pollution is linked with the increasing emergency hospital visits inducing cardiovascular diseases. More precisely, experimental and clinical evidences suggested that $\mathrm{PM}_{2.5}$ increases the pathogenesis of the cardiovascular diseases. Hence, more studies need to be done to elucidate the risks of $\mathrm{PM}_{2.5}$ associated with cardiovascular diseases.

\section{References}

[1] Guo, Y., Jia, Y., Pan, X., Liu, L. and Wichmann, H.E. (2009) The Association between Fine Particulate Air Pollution and Hospital Emergency Room Visits for Cardiovascular Diseases in Beijing, China. The Science of the Total Environment, 407, 4826-30. https://doi.org/10.1016/j.scitotenv.2009.05.022

[2] Brook, R.D., Rajagopalan, S., Pope III, C.A., Brook, J.R., Bhatnagar, A., Diez-Roux, 
A.V., Holguin, F., Hong, Y., Luepker, R.V., Mittleman, M.A., Peters, A., Siscovick, D., Smith Jr., S.C., Whitsel, L. and Kaufman, J.D. (2010) Particulate Matter Air Pollution and Cardiovascular Disease: An Update to the Scientific Statement from the American Heart Association. Circulation, 121, 2331-2378. https://doi.org/10.1161/CIR.0b013e3181dbece1

[3] Lozano, R., Naghavi, M., Foreman, K., Lim, S., Shibuya, K., Aboyans, V., Abraham, J., Adair, T., Aggarwal, R., Ahn, S.Y., Alvarado, M., Anderson, H.R., Anderson, L.M., Andrews, K.G., Atkinson, C., Baddour, L.M., Barker-Collo, S., Bartels, D.H., Bell, M.L., Benjamin, E.J., Bennett, D., Bhalla, K., Bikbov, B., Bin Abdulhak, A., Birbeck, G., Blyth, F., Bolliger, I., Boufous, S., Bucello, C., Burch, M., Burney, P., Carapetis, J., Chen, H., Chou, D., Chugh, S.S., Coffeng, L.E., Colan, S.D., Colquoun, S., Colson, K.E., Condon, J., Connor, M.D., Cooper, L.T., Corriere, M., Cortinovis, M., de Vaccaro, K.C., Couser, W., Cowie, B.C., Criqui, M.H., Cross, M., Dabhadkar, K.C., Dahodwala, N., De Leo, D., Degenhardt, L., Delossantos, A., Denenberg, J., Des Jarlais, D.C., Dharmaratne, S.D., Dorsey, E.R., Driscoll, T., Duber, H., Ebel, B., Erwin, P.J., Espindola, P., Ezzati, M., Feigin, V., Flaxman, A.D., Forouzanfar, M.H., Fowkes, F.G., Franklin, R., Fransen, M., Freeman, M.K., Gabriel, S.E., Gakidou, E., Gaspari, F., Gillum, R.F., Gonzalez-Medina, D., Halasa, Y.A., Haring, D., Harrison, J.E., Havmoeller, R., Hay, R.J., Hoen, B., Hotez, P.J., Hoy, D., Jacobsen, K.H., James, S.L., Jasrasaria, R., Jayaraman, S., Johns, N., Karthikeyan, G., Kassebaum, N., Keren, A., Khoo, J.P., Knowlton, L.M., Kobusingye, O., Koranteng, A., Krishnamurthi, R., Lipnick, M., Lipshultz, S.E., Ohno, S.L., Mabweijano, J., MacIntyre, M.F., Mallinger, L., March, L., Marks, G.B., Marks, R., Matsumori, A., Matzopoulos, R., Mayosi, B.M., McAnulty, J.H., McDermott, M.M., McGrath, J., Mensah, G.A., Merriman, T.R., Michaud, C., Miller, M., Miller, T.R., Mock, C., Mocumbi, A.O., Mokdad, A.A., Moran, A., Mulholland, K., Nair, M.N., Naldi, L., Narayan, K.M., Nasseri, K., Norman, P., O’Donnell, M., Omer, S.B., Ortblad, K., Osborne, R., Ozgediz, D., Pahari, B., Pandian, J.D., Rivero, A.P., Padilla, R.P., Perez-Ruiz, F., Perico, N., Phillips, D., Pierce, K., Pope, 3rd, C.A., Porrini, E., Pourmalek, F., Raju, M., Ranganathan, D., Rehm, J.T., Rein, D.B., Remuzzi, G., Rivara, F.P., Roberts, T., De Leon, F.R., Rosenfeld, L.C., Rushton, L., Sacco, R.L., Salomon, J.A., Sampson, U., Sanman, E., Schwebel, D.C., Segui-Gomez, M., Shepard, D.S., Singh, D., Singleton, J., Sliwa, K., Smith, E., Steer, A., Taylor, J.A., Thomas, B., Tleyjeh, I.M., Towbin, J.A., Truelsen, T., Undurraga, E.A., Venketasubramanian, N., Vijayakumar, L., Vos, T., Wagner, G.R., Wang, M., Wang, W., Watt, K., Weinstock, M.A., Weintraub, R., Wilkinson, J.D., Woolf, A.D., Wulf, S., Yeh, P.H., Yip, P., Zabetian, A., Zheng, Z.J., Lopez, A.D., Murray, C.J., AlMazroa, M.A. and Memish, Z.A. (2012) Global and Regional Mortality from 235 Causes of Death for 20 Age Groups in 1990 and 2010: A Systematic Analysis for the Global Burden of Disease Study 2010. Lancet, 380, 2095-2128. https://doi.org/10.1016/S0140-6736(12)61728-0

[4] Pope, 3rd, C.A. and Dockery, D.W. (2006) Health Effects of Fine Particulate Air Pollution: Lines That Connect. Journal of the Air \& Waste Management Association, 56, 709-42. https://doi.org/10.1080/10473289.2006.10464485

[5] Schwarze, P.E., Ovrevik, J., Lag, M., Refsnes, M., Nafstad, P., Hetland, R.B. and Dybing, E. (2006) Particulate Matter Properties and Health Effects: Consistency of Epidemiological and Toxicological Studies. Human \& Experimental Toxicology, 25, 559-579. https://doi.org/10.1177/096032706072520

[6] Brook, R.D. (2007) Is Air Pollution a Cause of Cardiovascular Disease? Updated Review and Controversies. Reviews on Environmental Health, 22, 115-137. https://doi.org/10.1515/REVEH.2007.22.2.115 
[7] Adar, S.D. and Kaufman, J.D. (2007) Cardiovascular Disease and Air Pollutants: Evaluating and Improving Epidemiological Data Implicating Traffic Exposure. Inhalation Toxicology, 19, 135-49. https://doi.org/10.1080/08958370701496012

[8] Bai, N., Khazaei, M., van Eeden, S.F. and Laher, I. (2007) The Pharmacology of Particulate Matter Air Pollution-Induced Cardiovascular Dysfunction. Pharmacology \& Therapeutics, 113, 16-29. https://doi.org/10.1016/j.pharmthera.2006.06.005

[9] Lippi, G., Favaloro, E.J., Franchini, M. and Guidi, G.C. (2008) Air Pollution and Coagulation Testing: A New Source of Biological Variability? Thrombosis Research, 123, 50-54. https://doi.org/10.1016/j.thromres.2008.04.010

[10] Pope, 3rd, C.A., Burnett, R.T., Thurston, G.D., Thun, M.J., Calle, E.E., Krewski, D. and Godleski, J.J. (2004) Cardiovascular Mortality and Long-Term Exposure to Particulate Air Pollution: Epidemiological Evidence of General Pathophysiological Pathways of Disease. Circulation, 109, 71-77. https://doi.org/10.1161/01.CIR.0000108927.80044.7F

[11] Giorgini, P., Rubenfire, M., Das, R., Gracik, T., Wang, L., Morishita, M., Bard, R.L., Jackson, E.A., Fitzner, C.A., Ferri, C. and Brook, R.D. (2015) Particulate Matter Air Pollution and Ambient Temperature: Opposing Effects on Blood Pressure in High-Risk Cardiac Patients. Journal of Hypertension, 33, 2032-2038. https://doi.org/10.1097/HJH.0000000000000663

[12] Auchincloss, A.H., Diez Roux, A.V., Dvonch, J.T., Brown, P.L., Barr, R.G., Daviglus, M.L., Goff, D.C., Kaufman, J.D. and O’Neill, M.S. (2008) Associations between Recent Exposure to Ambient Fine Particulate Matter and Blood Pressure in the Multi-Ethnic Study of Atherosclerosis (MESA). Environmental Health Perspectives, 116, 486-491. https://doi.org/10.1289/ehp.10899

[13] Park, S.K., O’Neill, M.S., Vokonas, P.S., Sparrow, D., Spiro, 3rd, A., Tucker, K.L., Suh, H., Hu, H. and Schwartz, J. (2008) Traffic-Related Particles Are Associated with Elevated Homocysteine: The VA Normative Aging Study. American Journal of Respiratory and Critical Care Medicine, 178, 283-289. https://doi.org/10.1164/rccm.200708-1286OC

[14] Baccarelli, A., Zanobetti, A., Martinelli, I., Grillo, P., Hou, L., Lanzani, G., Mannucci, P.M., Bertazzi, P.A. and Schwartz, J. (2007) Air Pollution, Smoking, and Plasma Homocysteine. Environmental Health Perspectives, 115, 176-181. https://doi.org/10.1289/ehp.9517

[15] Bind, M.A., Baccarelli, A., Zanobetti, A., Tarantini, L., Suh, H., Vokonas, P. and Schwartz, J. (2012) Air Pollution and Markers of Coagulation, Inflammation, and Endothelial Function: Associations and Epigene-Environment Interactions in an Elderly Cohort. Epidemiology, 23, 332-340. https://doi.org/10.1097/EDE.0b013e31824523f0

[16] Delfino, R.J., Staimer, N., Tjoa, T., Polidori, A., Arhami, M., Gillen, D.L., Kleinman, M.T., Vaziri, N.D., Longhurst, J., Zaldivar, F. and Sioutas, C. (2008) Circulating Biomarkers of Inflammation, Antioxidant Activity, and Platelet Activation Are Associated with Primary Combustion Aerosols in Subjects with Coronary Artery Disease. Environmental Health Perspectives, 116, 898-906. https://doi.org/10.1289/ehp.11189

[17] Delfino, R.J., Staimer, N., Tjoa, T., Gillen, D.L., Polidori, A., Arhami, M., Kleinman, M.T., Vaziri, N.D., Longhurst, J. and Sioutas, C. (2009) Air Pollution Exposures and Circulating Biomarkers of Effect in a Susceptible Population: Clues to Potential Causal Component Mixtures and Mechanisms. Environmental Health Perspectives, 117, 1232-1238. https://doi.org/10.1289/ehp.0800194

[18] Devereaux, P.J. and Sessler, D.I. (2015) Cardiac Complications in Patients Under- 
going Major Noncardiac Surgery. The New England Journal of Medicine, 373, 2258-2269. https://doi.org/10.1056/NEJMra1502824

[19] Qiu, C. and Fratiglioni, L. (2015) A Major Role for Cardiovascular Burden in Age-Related Cognitive Decline. Nature Reviews. Cardiology, 12, 267-277. https://doi.org/10.1038/nrcardio.2014.223

[20] Huedo-Medina, T.B., Garcia, M., Bihuniak, J.D., Kenny, A. and Kerstetter, J. (2016) Methodologic Quality of Meta-Analyses and Systematic Reviews on the Mediterranean Diet and Cardiovascular Disease Outcomes: A Review. The American Journal of Clinical Nutrition, 103, 841-850. https://doi.org/10.3945/ajcn.115.112771

[21] Lim, S.S., Vos, T., Flaxman, A.D., Danaei, G., Shibuya, K., Adair-Rohani, H., Amann, M., Anderson, H.R., Andrews, K.G., Aryee, M., Atkinson, C., Bacchus, L.J., Bahalim, A.N., Balakrishnan, K., Balmes, J., Barker-Collo, S., Baxter, A., Bell, M.L., Blore, J.D., Blyth, F., Bonner, C., Borges, G., Bourne, R., Boussinesq, M., Brauer, M., Brooks, P., Bruce, N.G., Brunekreef, B., Bryan-Hancock, C., Bucello, C., Buchbinder, R., Bull, F., Burnett, R.T., Byers, T.E., Calabria, B., Carapetis, J., Carnahan, E., Chafe, Z., Charlson, F., Chen, H., Chen, J.S., Cheng, A.T., Child, J.C., Cohen, A., Colson, K.E., Cowie, B.C., Darby, S., Darling, S., Davis, A., Degenhardt, L., Dentener, F., Des Jarlais, D.C., Devries, K., Dherani, M., Ding, E.L., Dorsey, E.R., Driscoll, T., Edmond, K., Ali, S.E., Engell, R.E., Erwin, P.J., Fahimi, S., Falder, G., Farzadfar, F., Ferrari, A., Finucane, M.M., Flaxman, S., Fowkes, F.G., Freedman, G., Freeman, M.K., Gakidou, E., Ghosh, S., Giovannucci, E., Gmel, G., Graham, K., Grainger, R., Grant, B., Gunnell, D., Gutierrez, H.R., Hall, W., Hoek, H.W., Hogan, A., Hosgood, H.D., Hoy, D., Hu, H., Hubbell, B.J., Hutchings, S.J., Ibeanusi, S.E., Jacklyn, G.L., Jasrasaria, R., Jonas, J.B., Kan, H., Kanis, J.A., Kassebaum, N., Kawakami, N., Khang, Y.H., Khatibzadeh, S., Khoo, J.P., Kok, C., Laden, F., Lalloo, R., Lan, Q., Lathlean, T., Leasher, J.L., Leigh, J., Li, Y., Lin, J.K., Lipshultz, S.E., London, S., Lozano, R., Lu, Y., Mak, J., Malekzadeh, R., Mallinger, L., Marcenes, W., March, L., Marks, R., Martin, R., McGale, P., McGrath, J., Mehta, S., Mensah, G.A., Merriman, T.R., Micha, R., Michaud, C., Mishra, V., Mohd Hanafiah, K., Mokdad, A.A., Morawska, L., Mozaffarian, D., Murphy, T., Naghavi, M., Neal, B., Nelson, P.K., Nolla, J.M., Norman, R., Olives, C., Omer, S.B., Orchard, J., Osborne, R., Ostro, B., Page, A., Pandey, K.D., Parry, C.D., Passmore, E., Patra, J., Pearce, N., Pelizzari, P.M., Petzold, M., Phillips, M.R., Pope, D., Pope, C.A., Powles, J., Rao, M., Razavi, H., Rehfuess, E.A., Rehm, J.T., Ritz, B., Rivara, F.P., Roberts, T., Robinson, C., Rodriguez-Portales, J.A., Romieu, I., Room, R., Rosenfeld, L.C., Roy, A., Rushton, L., Salomon, J.A., Sampson, U., Sanchez-Riera, L., Sanman, E., Sapkota, A., Seedat, S., Shi, P., Shield, K., Shivakoti, R., Singh, G.M., Sleet, D.A., Smith, E., Smith, K.R., Stapelberg, N.J., Steenland, K., Stockl, H., Stovner, L.J., Straif, K., Straney, L., Thurston, G.D., Tran, J.H., Van Dingenen, R., van Donkelaar, A., Veerman, J.L., Vijayakumar, L., Weintraub, R., Weissman, M.M., White, R.A., Whiteford, H., Wiersma, S.T., Wilkinson, J.D., Williams, H.C., Williams, W., Wilson, N., Woolf, A.D., Yip, P., Zielinski, J.M., Lopez, A.D., Murray, C.J., Ezzati, M., AlMazroa, M.A. and Memish, Z.A. (2012) A Comparative Risk Assessment of Burden of Disease and Injury Attributable to 67 Risk Factors and Risk Factor Clusters in 21 Regions, 1990-2010: A Systematic Analysis for the Global Burden of Disease Study 2010. The Lancet, 380, 2224-2260. https://doi.org/10.1016/S0140-6736(12)61766-8

[22] Kampfrath, T., Maiseyeu, A., Ying, Z., Shah, Z., Deiuliis, J.A., Xu, X., Kherada, N., Brook, R.D., Reddy, K.M., Padture, N.P., Parthasarathy, S., Chen, L.C., Moffatt-Bruce, S., Sun, Q., Morawietz, H. and Rajagopalan, S. (2011) Chronic Fine Particulate Matter Exposure Induces Systemic Vascular Dysfunction via NADPH Oxidase and TLR4 Pathways. Circulation Research, 108, 716-726. 
https://doi.org/10.1161/CIRCRESAHA.110.237560

[23] Chen, R., Zhao, Z., Sun, Q., Lin, Z., Zhao, A., Wang, C., Xia, Y., Xu, X. and Kan, H. (2015) Size-Fractionated Particulate Air Pollution and Circulating Biomarkers of Inflammation, Coagulation, and Vasoconstriction in a Panel of Young Adults. Epidemiology, 26, 328-336. https://doi.org/10.1097/EDE.0000000000000273

[24] Wu, S., Deng, F., Wei, H., Huang, J., Wang, H., Shima, M., Wang, X., Qin, Y., Zheng, C., Hao, Y. and Guo, X. (2012) Chemical Constituents of Ambient Particulate Air Pollution and Biomarkers of Inflammation, Coagulation and Homocysteine in Healthy Adults: A Prospective Panel Study. Particle and Fibre Toxicology, 9, 49. https://doi.org/10.1186/1743-8977-9-49

[25] Marti, C.N., Khan, H., Mann, D.L., Georgiopoulou, V.V., Bibbins-Domingo, K., Harris, T., Koster, A., Newman, A., Kritchevsky, S.B., Kalogeropoulos, A.P. and Butler, J. (2014) Soluble Tumor Necrosis Factor Receptors and Heart Failure Risk in Older Adults: Health, Aging, and Body Composition (Health ABC) Study. Circulation: Heart Failure, 7, 5-11. https://doi.org/10.1161/CIRCHEARTFAILURE.113.000344

[26] Ploplis, V.A. (2011) Effects of Altered Plasminogen Activator Inhibitor-1 Expression on Cardiovascular Disease. Current Drug Targets, 12, 1782-1789. https://doi.org/10.2174/138945011797635803

[27] Blann, A.D., Nadar, S.K. and Lip, G.Y. (2003) The Adhesion Molecule P-Selection and Cardiovascular Disease. European Heart Journal, 24, 2166-2179. https://doi.org/10.1016/j.ehj.2003.08.021

[28] Hildebrandt, K., Ruckerl, R., Koenig, W., Schneider, A., Pitz, M., Heinrich, J., Marder, V., Frampton, M., Oberdorster, G., Wichmann, H.E. and Peters, A. (2009) Short-Term Effects of Air Pollution: A Panel Study of Blood Markers in Patients with Chronic Pulmonary Disease. Particle and Fibre Toxicology, 6, 25. https://doi.org/10.1186/1743-8977-6-25

[29] Chuang, K.J., Chan, C.C., Su, T.C., Lin, L.Y. and Lee, C.T. (2007) Associations between Particulate Sulfate and Organic Carbon Exposures and Heart Rate Variability in Patients with or at Risk for Cardiovascular Diseases. Journal of Occupational and Environmental Medicine, 49, 610-617. https://doi.org/10.1097/JOM.0b013e318058205b

[30] de Hartog, J.J., Lanki, T., Timonen, K.L., Hoek, G., Janssen, N.A., Ibald-Mulli, A., Peters, A., Heinrich, J., Tarkiainen, T.H., van Grieken, R., van Wijnen, J.H., Brunekreef, B. and Pekkanen, J. (2009) Associations between PM2.5 and Heart Rate Variability Are Modified by Particle Composition and Beta-Blocker Use in Patients with Coronary Heart Disease. Environmental Health Perspectives, 117, 105-115. https://doi.org/10.1289/ehp.11062

[31] Valavanidis, A., Fiotakis, K. and Vlachogianni, T. (2008) Airborne Particulate Matter and Human Health: Toxicological Assessment and Importance of Size and Composition of Particles for Oxidative Damage and Carcinogenic Mechanisms, Journal of Environmental Science and Health. Part C, Environmental Carcinogenesis \& Ecotoxicology Reviews, 26, 339-362. https://doi.org/10.1080/10590500802494538

[32] Wu, S., Deng, F., Niu, J., Huang, Q., Liu, Y. and Guo, X. (2010) Association of Heart Rate Variability in Taxi Drivers with Marked Changes in Particulate Air Pollution in Beijing in 2008. Environmental Health Perspectives, 118, 87-91.

[33] Dai, L., Zanobetti, A., Koutrakis, P. and Schwartz, J.D. (2014) Associations of Fine Particulate Matter Species with Mortality in the United States: A Multicity Time-Series Analysis. Environmental Health Perspectives, 122, 837-842. 
https://doi.org/10.1289/ehp.1307568

[34] Peng, R.D., Bell, M.L., Geyh, A.S., McDermott, A., Zeger, S.L., Samet, J.M. and Dominici, F. (2009) Emergency Admissions for Cardiovascular and Respiratory Diseases and the Chemical Composition of Fine Particle Air Pollution. Environmental Health Perspectives, 117, 957-963. https://doi.org/10.1289/ehp.0800185

[35] Dominici, F. and Mittleman, M.A. (2012) China's Air Quality Dilemma: Reconciling Economic Growth with Environmental Protection. JAMA, 307, 2100-2102. https://doi.org/10.1001/jama.2012.4601

[36] Li, M. and Zhang, L. (2014) Haze in China: Current and Future Challenges. Environmental Pollution, 189, 85-86. https://doi.org/10.1016/j.envpol.2014.02.024

[37] Zhou, M., He, G., Fan, M., Wang, Z., Liu, Y., Ma, J., Ma, Z., Liu, J., Liu, Y., Wang, L. and Liu, Y. (2015) Smog Episodes, Fine Particulate Pollution and Mortality in China. Environmental Research, 136, 396-404. https://doi.org/10.1016/j.envres.2014.09.038

[38] Xie, R., Seip, H.M., Wibetoe, G., Nori, S. and McLeod, C.W. (2006) Heavy Coal Combustion as the Dominant Source of Particulate Pollution in Taiyuan, China, Corroborated by High Concentrations of Arsenic and Selenium in PM10. The Science of the Total Environment, 370, 409-415. https://doi.org/10.1016/j.scitotenv.2006.07.004

[39] Kinoshita, T., Yamaguchi, K., Akita, S., Nii, S., Kawaizumi, F. and Takahashi, K. (2005) Hydrometallurgical Recovery of Zinc from Ashes of Automobile Tire Wastes. Chemosphere, 59, 1105-1111. https://doi.org/10.1016/j.chemosphere.2004.12.015

[40] Bruce, N., Perez-Padilla, R. and Albalak, R. (2000) Indoor Air Pollution in Developing Countries: A Major Environmental and Public Health Challenge. Bulletin of the World Health Organization, 78, 1078-1092.

[41] Albalak, R., Frisancho, A.R. and Keeler, G.J. (1999) Domestic Biomass Fuel Combustion and Chronic Bronchitis in Two Rural Bolivian Villages. Thorax, 54, 1004-1008. https://doi.org/10.1136/thx.54.11.1004

[42] WRI (1999) World Resources Institute, UNEP, UNDP, World Bank. 1998-99 World Resources: A Guide to the Global Environment. Oxford University Press, Oxford.

[43] Behera, D., Dash, S. and Malik, S.K. (1988) Blood Carboxyhaemoglobin Levels Following Acute Exposure to Smoke of Biomass Fuel. The Indian Journal of Medical Research, 88, 522-524.

[44] Xie, J., He, M. and Zhu, W. (2014) Acute Effects of Outdoor Air Pollution on Emergency Department Visits Due to Five Clinical Subtypes of Coronary Heart Diseases in Shanghai, China. Journal of Epidemiology, 24, 452-459. https://doi.org/10.2188/jea.JE20140044

[45] Kan, H., London, S.J., Chen, G., Zhang, Y., Song, G., Zhao, N., Jiang, L. and Chen, B. (2008) Season, Sex, Age, and Education as Modifiers of the Effects of Outdoor Air Pollution on Daily Mortality in Shanghai, China: The Public Health and Air Pollution in Asia (PAPA) Study. Environmental Health Perspectives, 116, 1183-1188. https://doi.org/10.1289/ehp.10851

[46] Fan, R., Li, J., Chen, L., Xu, Z., He, D., Zhou, Y., Zhu, Y., Wei, F. and Li, J. (2014) Biomass Fuels and Coke Plants Are Important Sources of Human Exposure to Polycyclic Aromatic Hydrocarbons, Benzene and Toluene. Environmental Research, 135, 1-8. https://doi.org/10.1016/j.envres.2014.08.021

[47] Li, J., He, J., Tang, R., Hu, W., Lan, Q., He, X., Li, Y. and Zhang, Y. (2015) Molecular Epidemiology Study in Xuanwei: The Relationship among Coal Type, Genotype 
and Lung Cancer Risk. Chinese Journal of Lung Cancer, 18, 16-22.

[48] Belleudi, V., Faustini, A., Stafoggia, M., Cattani, G., Marconi, A., Perucci, C.A. and Forastiere, F. (2010) Impact of Fine and Ultrafine Particles on Emergency Hospital Admissions for Cardiac and Respiratory Diseases. Epidemiology, 21, 414-423. https://doi.org/10.1097/EDE.0b013e3181d5c021

[49] Stafoggia, M., Samoli, E., Alessandrini, E., Cadum, E., Ostro, B., Berti, G., Faustini, A., Jacquemin, B., Linares, C., Pascal, M., Randi, G., Ranzi, A., Stivanello, E. and Forastiere, F. (2013) Short-Term Associations between Fine and Coarse Particulate Matter and Hospitalizations in Southern Europe: Results from the Med-Particles Project. Environmental Health Perspectives, 121, 1026-1033.

[50] Rodopoulou, S., Chalbot, M.C., Samoli, E., Dubois, D.W., San Filippo, B.D. and Kavouras, I.G. (2014) Air Pollution and Hospital Emergency Room and Admissions for Cardiovascular and Respiratory Diseases in Dona Ana County, New Mexico. Environmental Research, 129, 39-46. https://doi.org/10.1016/j.envres.2013.12.006

[51] Lu, F., Xu, D., Cheng, Y., Dong, S., Guo, C., Jiang, X. and Zheng, X. (2015) Systematic Review and Meta-Analysis of the Adverse Health Effects of Ambient PM2.5 and PM10 Pollution in the Chinese Population. Environmental Research, 136, 196-204. https://doi.org/10.1016/j.envres.2014.06.029

[52] Kim, H.S., Kim, D.S., Kim, H. and Yi, S.M. (2012) Relationship between Mortality and Fine Particles during Asian Dust, Smog-Asian Dust, and Smog Days in Korea. International Journal of Environmental Health Research, 22, 518-530. https://doi.org/10.1080/09603123.2012.667796

[53] Lee, H., Honda, Y., Hashizume, M., Guo, Y.L., Wu, C.F., Kan, H., Jung, K., Lim, Y.H., Yi, S. and Kim, H. (2015) Short-Term Exposure to Fine and Coarse Particles and Mortality: A Multicity Time-Series Study in East Asia. Environmental Pollution, 207, 43-51. https://doi.org/10.1016/j.envpol.2015.08.036

[54] Michikawa, T., Ueda, K., Takeuchi, A., Kinoshita, M., Hayashi, H., Ichinose, T. and Nitta, H. (2015) Impact of Short-Term Exposure to Fine Particulate Matter on Emergency Ambulance Dispatches in Japan. Journal of Epidemiology and Community Health, 69, 86-91. https://doi.org/10.1136/jech-2014-203961

[55] Guo, Y., Tong, S., Zhang, Y., Barnett, A.G., Jia, Y. and Pan, X. (2010) The Relationship between Particulate Air Pollution and Emergency Hospital Visits for Hypertension in Beijing, China. The Science of the Total Environment, 408, 4446-4450. https://doi.org/10.1016/j.scitotenv.2010.06.042

[56] Su, C., Breitner, S., Schneider, A., Liu, L., Franck, U., Peters, A. and Pan, X. (2016) Short-Term Effects of Fine Particulate Air Pollution on Cardiovascular Hospital Emergency Room Visits: A Time-Series Study in Beijing, China. International Archives of Occupational and Environmental Health, 89, 641-657.

https://doi.org/10.1007/s00420-015-1102-6

[57] Xie, W., Li, G., Zhao, D., Xie, X., Wei, Z., Wang, W., Wang, M., Li, G., Liu, W., Sun, J., Jia, Z., Zhang, Q. and Liu, J. (2015) Relationship between Fine Particulate Air Pollution and Ischaemic Heart Disease Morbidity and Mortality. Heart, 101, 257-263. https://doi.org/10.1136/heartjnl-2014-306165

[58] Huang, F., Li, X., Wang, C., Xu, Q., Wang, W., Luo, Y., Tao, L., Gao, Q., Guo, J., Chen, S., Cao, K., Liu, L., Gao, N., Liu, X., Yang, K., Yan, A. and Guo, X. (2015) PM2.5 Spatiotemporal Variations and the Relationship with Meteorological Factors during 2013-2014 in Beijing, China. PLoS ONE, 10, e0141642.

https://doi.org/10.1371/journal.pone.0141642 


\section{Abbreviation}

Al Aluminium, Ba Barium, Cd Cadmium, Cl Chlorine, Co Cobalt, CRP C-reactive protein, ET-1 Endothelin 1, FFluorine, Fe Iron, ICAM-1 Intercellular adhesion molecule 1, MCP-1 Monocyte chemoattractant protein 1, Mg Magnesium, Mn Manganese, NADPH Nicotinamide adenine dinucleotide phosphate, $\mathrm{NO}_{3}$ Nitrate, PAI-1 Plasminogen activator inhibitor-1, PAI-1 Plasminogen activator inhibitor-1, $\mathrm{Pb}$ Lead, $\mathrm{SO}_{4}$ Sulfate, Ti Titanium, TLR4 Toll-like receptor 4, TNF- $\alpha$ Tumor necrosis factor alpha, V Vanadium, VCAM-1 Vascular cell adhesion protein 1, vWF Von Willebrand factor, Zn Zinc. 